\title{
Execution Of Rights Under The Designation Of Liability By Auction Of State Court Of Pekalongan
}

\author{
Eka Hendra Muspiyanto ${ }^{1}$, Tutut Suciati Handayani ${ }^{2}$ and Gunarto ${ }^{3}$
}

Abstract. This researchaims to determine how the execution Encumbrance through an auction to be determined by the District Court of Pekalongan and what weaknesses and execution Mortgage solution through an auction to be determined by the District Court of Pekalongan. Mortgage execution through an auction based on the determination District Court of Pekalongan held upon the request of the winning bidder. Request execution Mortgage by auction by the auction winner made after terlelang not willing to vacate voluntarily execution object. Mortgage weakness execution through an auction based on the determination that the District Court Pekalongan there are two opinions on the application process execution Encumbrance through an auction to be determined by the District Court if there is a lawsuit against the object of the auction following the application execution. The first opinion the petition can still be processed until the issuance of the determination of the District Court. The second opinion request for execution should be delayed pending completion of a lawsuit against the auction object. This is due to the absence of explicit provision governing the execution Mortgage application process through the auction in case there is a lawsuit in the execution object, especially if there is a lawsuit against the object of execution in case the application execution has been carried out. Similarly, in the case of the emergence of a lawsuit before the application for execution is done. Whether the execution can be carried out or not. This gives rise to a variety of opinions that may be detrimental to the winning bidder. For it should be no explicit provision governing the execution Mortgage application process through the auction in case there is a lawsuit in the execution object other drawback is the resistance of the current terkesekusi will be executed.

Keywords: Execution; Mortgage; Auctions; Determination.

\section{Introduction}

Execution Mortgage with executorial title can be done for under Article 14 paragraph (2) Law No. 4 of 1996 on Mortgage, Mortgage certificate as a sign or evidence of any Encumbrance containing tittle which reads "For The Sake Of Justice Under The One Almighty God". Encumbrance Certificate has the power executorial the same legal force court decision that remain.

The purpose of land rights auction is for the buyer to the auction can legally control and use of land. Land is an object that has a high economic value. Existing legislation relating to the auction sometimes unable to accommodate the cases occurred in masyarakat.Peralihan rights by auction only be registered if it is evidenced by the minutes of the auction quote made by officials in both the auction Auctions and auction voluntary execution. ${ }^{4}$

\footnotetext{
1 Master of Notary's , Faculty of Law, Universitas Islam Sultan Agung email ekahendra272727@gmail.com

2 Students of Master of Law, Faculty of Law, Universitas Islam Sultan Agung email tututshs@gmail.com

${ }^{3}$ Professor of Faculty of Law UNISSULA

${ }^{4}$ Boedi Harsono 2008 Hukum Agraria Indonesia Sejarah Pembentukan Undang-Undang Pokok Agraria Isi dan Pelaksanaannya Volume 1 Cet. XII Djambatan Jakarta p. 516.
} 
Laws have guaranteed legal certainty for auction buyers who are clearly stated in the Reglement Vendu, HIR, as well as the Minister of Finance Regulation No. 27 / PMK.06 / 2016 on Guidelines for the Implementation of the Auction. Vendu Reglement are rules that govern the fundamental principles of the auction which has been in effect since April 1, 1908. In general Vendu Reglement only set about organizing the auction, the auctioneer or currently referred to as auction officials, the parts and the contents of the minutes of the auction. Vendu Reglement in Article 42, states that the winner of the auction are entitled to quote the minutes of the auction as the deed of sale of objects auction. Excerpts treatise auction will be used as a deed of sale for the benefit auction behind the object name when an auction is immovable. ${ }^{5}$

The auction winner can master the execution Mortgage auction object after the implementation of the obligations of the winning bidder. Such obligations as specified in Article 22 and Article 75 Vendu Reglement Finance Minister Regulation No. 27 / PMK.06 / 2016 on Implementation Guidelines Auction noted that buyers are prohibited from taking or control of goods bought before fulfilling the payment obligations Auction and taxes or other valid according to the rules legislation. If the winner of the auction has not carried out its obligations, the winning bidder is not allowed to control the object.

In practice, the winning bidder who has carried out its obligations often are not able to master the object of the auction because the auction still control object executed auctions and is not willing to give the right bidder for control of the auction object. If so then attempt to do the winning bidder is to make the petition to the District Court so held an auction object execution.

Mortgage registration execution request through auctions in the District Court by the winning bidder will arise in the event of a lawsuit from the executed auction. The first problem, the lawsuit arose before the filing of the petition Encumbrance by auction and the second concerns the lawsuit following the application execution Encumbrance by auction by the auction winner.

On the first issue is a lawsuit arising prior to the filing of request execution Encumbrance by auction is not really a problem. If this occurs then the application process execution Encumbrance by auction postponed until he tore a lawsuit. On the second issue is the existence of a lawsuit following the application execution Encumbrance by auction by the auction winner raises two arguments. The first opinion Mortgage application process execution by the winner of the auction must be postponed if there is a lawsuit following the application execution Mortgage through auctions. The second opinion request Mortgage execution must still be processed even if there is a lawsuit following the application execution Encumbrance by auction by the auction winner.

Another problem is the execution of Guarantees Mortgage through an auction to be determined by the District Court did not always run smoothly, such as their resistance terlelang to measures to be taken against collateral Mortgage. This causes delays execution Encumbrance could even fail.

Problems formulated this research that bHow can the execution Encumbrance through an auction to be determined by the District Court of Pekalongan and what weaknesses and execution Mortgage solution through an auction to be determined by the District Court of Pekalongan

\section{Research Methods}

\footnotetext{
${ }^{5}$ Carina Megarisa Mboeik 2016 Hak Sempurna Yang Melekat Pada Pemenang Lelang (Lelang Benda Tidak Bergerak/Tanah) article p. 5.
} 
This research method is socio-juridical, the research done in the field through interviews with respondents as the primary data and examine the library materials as secondary data, or so-called research literature

This research is a descriptive research. Through a descriptive study is expected to problems concerning the execution of the Mortgage through an auction to be determined by the District Court of Pekalongan be described clearly and deeply so as to obtain a good understanding and correct.

Data that are used this research is primary data and secondary data. Primary data is data obtained directly from the source through the interview. Primary data of this study is the result of interviews with judges regarding the execution of the Mortgage through an auction to be determined by the District Court of Pekalongan. Secondary data, is data obtained from the literature. ${ }^{6}$ Secondary data is data derived from the literature or books relating to the legal norms that has to do with the subject matter under study.

Once the data is collected, the next step is data analysis methods. The analytical method used is qualitative descriptive analysis. Given the data used is qualitative data, then after the data has been collected, clarified associated with the theory and take a decision or conclusion.

\section{Results And Discussion}

\subsection{Implementation of Execution Mortgage through Auction Based Determination of State Court of Pekalongan}

On the implementation of credit, especially those conducted in the banking operations is necessary to guarantee objects. Objects guarantees necessary to ensure the repayment of debt / credit of the debtor in the event the debtor in default or broken a promise not to repay the debts. In the banking business credit guarantees generally in the form of land rights granted dependents.

Practice credit agreement between creditors and debtors do not always run smoothly. Sometimes problems arise in the credit agreement as their default. One of the efforts to resolve debt redemption event of default is not the debtor, namely through the execution of the object guarantees for debts of the debtor.

If the debtor in default then the lender may make the execution of collateral objects. For objects that encumbered land collateral Mortgage execution can be done through:

- Sales Mortgage object under his hand.

It is based on the provisions of Article 20 (2) of Law No. 4 of 1996 on Mortgage.

- Parate execution. It is based on the provisions of Article 6 of Law No. 4 of 1996 on Mortgage which states that if a breach dibeitur first Mortgage holders have the right to sell the object of Encumbrance on his own authority through public tender and take repayment of its receivable from the sale proceeds.

- Execution Mortgage District Court. Execution Mortgage District Court based on the provisions of Article 224 HIR / 258 RBg / Article 14 paragraph (2) and (3) of Law No. 4 of 1996 on Mortgage and implementation.

Execution Mortgage through auction, the winning bidder in accordance with Article 42 Vendu Reglement, the winning bidder is entitled to retain a copy or quote diotentikkan news event or quote the minutes of the auction. Auction treatise quote is used as a deed of sale for the benefit of the auction through the object name.

\footnotetext{
${ }^{6}$ Ronny Hanitijo Soemitro. 1988 Metodologi Penelitian Hukum dan Jurimetri Ghalia Indonesia Ghalia Indonesia Jakarta p. 10.
} 
Based on the minutes of the auction means a shift of the rights of terlelang to the winning bidder. It is referred to in Article 41 paragraph (1) of Government Regulation No. 24 of 1997 on Land Registration, namely the minutes of the auction have the same status as the deed of sale made by the Notary Official (PPAT) which is used as a basis for registering transfer of rights over land to the land Office. It is also determined in Article 94 paragraph (2) letter aRegulation of the Minister of Finance (KMK) No. 27 / PMK.06 / 2016 on Implementation Guidelines stating Auction Buyer states that gained Quotes" Minutes of the Auction as Sale and Purchase Agreements for the interests behind the name or Grosse Minutes of the Auction as needed

Submission of documents related to ownership of the goods, the auction winner is entitled to retain the original documents of ownership of the object of the auction. In case the seller / owner of the goods submit the original documents of title to the official auction, officials of the auction should submit the original documents of title and / or goods are auctioned to buyers, a maximum of 1 (one) working days after the buyer show proof of full payment and submit proof of deposit Customs Acquisition Land and Building (BPHTB). Based on the above provision the auction winner can master object auctioned or auction and ask the party that controls the object of the auction to auction the objects vacate voluntarily. But in general, the party that controls terlelang or do not want to empty the auction object. If this occurs the auction winner may submit the petition to the District Court to conduct the auction by ordering the execution object auctioned or party that controls the auction object to empty the auction object. Similarly, what happened in the execution of the execution Encumbrance through auctions in the jurisdiction of the District Court of Pekalongan.

\subsection{Weakness and Implementation of Execution Mortgage Solutions through Auction Based Determination the District Court of Pekalongan}

Mortgage practice execution request through an auction based on the determination District Court of Pekalongan may be hampered if there is a lawsuit against the execution Encumbrance through lelang.Terdapat two opinions on the application process execution Encumbrance through an auction to be determined by the District Court if there is a lawsuit against the object of the auction following the application execution. The first opinion the petition can still be processed until the issuance of the determination of the District Court. The second opinion request for execution should be delayed pending completion of a lawsuit against the auction object.

At first the opinion that the petition can still be processed until the issuance of the determination of the District Court is not a problem until the implementation of the execution. In the event of such applicant can still get immediate execution rights to the object of the auction won. Regarding the lawsuit filed by the debtor can be processed properly.

For the second opinion that the petition should be delayed pending settlement of a lawsuit against the object of the auction may be detrimental to the winning bidder. In this case the winning bidder requesting the execution delayed getting its due because it had to wait for the completion of a lawsuit against the object of the auction by the debtor. Though civil cases take a long time to completion. Moreover, if in the suit are the remedies of appeal, until the appeal can take many years. If the winner of the auction is a good faith purchaser then the winner of the auction is not protected their rights.

If you look at the various legislations regarding Mortgage execution, then it should be the petition submitted by the winning bidder or auction buyers with good intention must be executed first if that applies for execution before the onset of action on the object of execution. The main thing being the reason that the provisions of Article 14 of Law No. 4 
of 1996 on Mortgage which states that: (1) As proof of the Mortgage, the Land Office publishes Encumbrance certificate in accordance with the legislation in force. (2) Certificate of Dependents referred to in paragraph (1) shall tittle with the words "For The Sake Of Justice Under The Almighty God". (3) Certificate referred to in paragraph (2) have the same executorial power with a court ruling has obtained permanent legal kekeuatan and serve as a substitute grosse acte hypotheek along over land rights. (4) Unless otherwise agreed, the certificate of land rights that have been stamped loading Mortgage notes referred to in Article 13 paragraph (3) be returned to the holders of land rights are concerned. (5) Certificate of Mortgage Encumbrance submitted to shareholders. certificate of land rights that have been stamped loading Mortgage notes referred to in Article 13 paragraph (3) be returned to the holders of land rights are concerned. (5) Certificate of Mortgage Encumbrance submitted to shareholders. certificate of land rights that have been stamped loading Mortgage notes referred to in Article 13 paragraph (3) be returned to the holders of land rights are concerned. (5) Certificate of Mortgage Encumbrance submitted to shareholders.

In addition to the minutes of the auction gross deed also contained excerpts tittle and binding as Encumbrance Certificate and the judge's decision. This gives legal force to the winning bidder that met their rights, especially the right to master the object of the auction.

Based on the provisions of the Certificate of Dependents have the power excecutorial the same legal force with a court ruling has had permanent legal force. So if there is a request for execution of Encumbrance through auctions in the District Court must still be processed and carried out the execution without waiting for a lawsuit settlement in a lawsuit arising following the application execution. In this case the winner of the auction is a third party should be protected from any Encumbrance.

Furthermore, if later it turns out a lawsuit filed against Mortgage object that has implemented the execution is denied, a mechanism that can be taken in the form of tort, addressed to the applicant not to the winning bidder auction. It is as specified by Article 195 HIR / 206 RBG. It is an attempt to provide legal protection to the winner / buyer auction well-meaning.

Occurrence of opinions about the execution process Encumbrance by auction at the stage of appeal mentioned above given the absence of explicit provision governing the application process execution Encumbrance by auction in case there is a lawsuit on the object of execution, particularly if there is a lawsuit against the object of execution in case the application execution have been done. Similarly, in the case of the emergence of a lawsuit before the application for execution is done. Whether the execution can be carried out or not. This gives rise to a variety of opinions that may be detrimental to the winning bidder.

In fact the weakness of the execution of the Mortgage through an auction to be determined by the District Court of Pekalongan not stop at the application stage. Practice of execution by auction to be determined by the District Court of Pekalongan also happening on the pitch as the execution. The weakness that always comes up is the resistance of the executed to vacate the execution object.

One reason put forward is executed the resistance that is still their willingness to repay their debts executed even though the object of Mortgage been conducted auctions, or any appeal is still running after the issuance of the determination of execution. For that reason it is not uncommon executed when deploying future will be implemented execution.

To overcome this, the execution is done through two approaches, persuasive and repressive approach. Persuasive negotiations between the winner of the auction to be executed, by way of compensation (damages, costs or expenses emptying or extend / 
renew the lease). If persuasion does not work then carried out repressive attempts by forceful measures. This was carried out under the provisions of Article 200 paragraph (11) HIR, which states that if the defeated party does not want to leave the items do not move it, then the Chairman of the Court or magishaat authorized to give a warrant to a person entitled to foreclose, so if necessary with the help of the police,

\section{Closing}

\subsection{Conclusion}

- Mortgage execution through an auction based on the determination District Court of Pekalongan held upon the request of the winning bidder. Request execution Mortgage by auction by the auction winner made after terlelang not willing to vacate voluntarily execution object.

- The negative aspect of Mortgage execution through an auction to be determined by the District Court of Pekalongan which are two opinions on the application process execution Encumbrance through an auction to be determined by the District Court if there is a lawsuit against the object of the auction following the application execution. The first opinion the petition can still be processed until the issuance of the determination of the District Court. The second opinion request for execution should be delayed pending completion of a lawsuit against the auction object. this is due to the absence of explicit provision governing the execution Mortgage application process through the auction in case there is a lawsuit in the execution object, especially if there is a lawsuit against the object of execution in case the application execution has been carried out. Similarly, in the case of the emergence of a lawsuit before the application for execution is done. Whether the execution can be carried out or not. This gives rise to a variety of opinions that may be detrimental to the winning bidder. The other drawback is the resistance of the current terkesekusi will be executed. The solution is a persuasive approach execution costs for damages / discharge and repressive form of forceful measures in execution

\subsection{Suggestion}

- Based on the foregoing, it is suggested there should be explicit provision governing the execution Mortgage application process through the auction in case there is a lawsuit in the execution object, especially if there is a lawsuit against the object of execution in case the application execution has been carried out. Similarly, in the case of the emergence of a lawsuit before the application for execution is done. Whether the execution can be carried out or not. This is to provide legal certainty in the execution process Encumbrance through an auction to be determined by the District Court.

\section{References}

[1] Boedi Harsono 2008 Hukum Agraria Indonesia Sejarah Pembentukan Undang-Undang Pokok Agraria Isi dan Pelaksanaannya Volume 1 Cet. XII Djambatan Jakarta.

[2] Carina Megarisa Mboeik 2016 Hak Sempurna Yang Melekat Pada Pemenang Lelang (Lelang Benda Tidak Bergerak/Tanah) article

[3] Ronny Hanitijo Soemitro. 1988 Metodologi Penelitian Hukum dan Jurimetri Ghalia Indonesia Ghalia Indonesia Jakarta. 